\title{
Dini Yapılar ve Kent Kimliği İlişkisi Üzerine Bir Değerlendirme: Trabzon Örneği ${ }^{1}$
}

\author{
Demet Yilmaz Yildirım ${ }^{2}$ \\ ORCID: 0000-0001-8894-3385
}

\author{
Şeyma Yetim ${ }^{3}$ \\ ORCID: 0000-0001-9741-9761
}

\section{Öz}

Her yapı kentsel bütün içinde yerini alarak kent kimliğine pozitif veya negatif olarak katkıda bulunmaktadır. Dini yapılar da biçimlenme ve konumlanma açısından kent dokusunda velveya kent siluetinde farklılıkları, tekillikleri veya egemenlikleriyle öne çıkan ve kullanıcı belleğinde kalıcı izler bırakan yapılardır. Hatta günümüzde dini yapıların biçimlenmesinin ötesinde konumlandırıldığı yerin yapıya özgünlük katmakta daha da etkili olduğu görülmektedir. Ayrıca bu yapılarda yapılanın ve yaptıranın gücünü görmek mümkündür. Tüm bunlar dini yapıların imaj üzerinden kent kimliğindeki yerini ve önemini ortaya koymaktadır. Çalışmada Trabzon'da dini yapıların kentle ilişkisini işaret öğesi olma potansiyelleri üzerinden ortaya koymak ve dini yapıların kent bütünündeki yerini tartışmak amacıyla fiziksel ve işlevsel analizler yapılmıştır. Bu analizlerde Coğrafi Bilgi Sistemi (GIS) üzerinden ArcMap 10.3 ve ArcScene 10.3 kullanılmıştır. Trabzon kent merkezi sınırları içinde yapılan çalışma kapsamında analizlerde öne çıkan dini yapular tespit edilerek, bu yapıların çevrelerinde yapılacak düzenlemelere veya yeni yapılacak dini yapıların konumlarını belirlenmesine yönelik veriler ortaya konmuştur.

Anahtar Kelimeler: Kimlik, imaj, işaret öğesi, dini yapı, Coğrafi Bilgi Sistemi (GIS)

\footnotetext{
${ }^{1}$ Bu çalışma, Dr. Öğr. Üyesi Demet Yılmaz Yıldırım danışmanlığında Şeyma Yetim tarafından hazırlanan “Dini Yapıların İşaret Öğesi Olma Potansiyeli: Trabzon Örneği” isimli yüksek lisans tezinden üretilmiştir.

2 Dr. Öğr. Üyesi, Karadeniz Teknik Üniversitesi, E-mail: yilmazdemett@ktu.edu.tr

3 Arş. Gör., Recep Tayyip Erdoğan Üniversitesi, E-mail: seyma.yetim@erdogan.edu.tr

idealkent (c) Kent Araştırmaları Dergisi (Journal of Urban Studies) 


\title{
An Evaluation on the Relationship Between Religious Buildings and Urban Identity: The Case of Trabzon ${ }^{4}$
}

\author{
Demet Yilmaz Yildirim ${ }^{5}$ \\ ORCID: 0000-0001-8894-3385
}

\author{
Şeyma Yetim 6 \\ ORCID: 0000-0001-9741-9761
}

\begin{abstract}
Each building contributes positively or negatively to the urban identity by taking its place in the urban whole. Religious buildings are also the structures that stand out with their differences, singularities or dominance in the urban texture and / or city skyline in terms of shaping and positioning and leave permanent marks in the user memory. Even today, it is seen that the placing of religious buildings beyond the shaping is even more effective in adding originality to the structure. All these reveal the place and importance of religious buildings in urban identity through image. In this study, physical and functional analyzes are carried out in order to reveal the relation of religious buildings with the city in Trabzon in terms of their potential as landmark and to discuss the place of religious buildings in the whole city. ArcMap 10.3 and ArcScene 10.3 are used in these analyzes. Within the scope of the study conducted within the boundaries of Trabzon city center, the prominent religious buildings were determined in the analysis, and the data regarding the arrangements to be made in the surroundings of these buildings or the determination of the location of the new religious buildings to be built.
\end{abstract}

Keywords: Identity, image, landmark, religious building, Geographic Information System (GIS)

\footnotetext{
${ }^{4}$ This study was produced from the master's thesis titled "The Potential of Religious Buildings on The Landmark: Trabzon Example" prepared by Şeyma Yetim under the supervision of Asts. Prof. Demet Yilmaz Yildırım.

${ }^{5}$ Asts. Prof., Karadeniz Technical University, E-mail: yilmazdemett@ktu.edu.tr

${ }_{6}^{6}$ R.A., Recep Tayyip Erdoğan University, E-mail: seyma.yetim@erdogan.edu.tr

idealkent (c) Kent Araştırmaları Dergisi (Journal of Urban Studies) 


\section{Giriş}

Küreselleşme her alanda olduğu gibi kentsel çevreleri de etkileyerek kentlerin kimlik öğelerinin kaybolmasina neden olmuştur. Günümüzde kentte kimlik sağlayan birçok öğe kentlerin bu karmaşık kent dokusunda algılanamamaktadır. Bu durum kent kimliğini tartışır hale getirmiştir. Oysa kimlik, bir taraftan kentleri birbirinden farklılaştırarak onları tanınır hale getirirken diğer taraftan kullanıcısı olan insanların kentlerinde kaybolmadan hareket edebilmelerini, dolayısıyla kendilerini güvende hissetmelerini, kentlerini sahiplenmelerini ve oraya ait hissetmelerini sağlamaktadır.

Kent kimliği; sosyo-kültürel yapı, sosyo-ekonomik yapı, fiziki çevre ve imaj öğeleri ile belirlenmektedir. Bülüç (2017), kent kimliği bileşenlerini somut (doğal çevre özellikleri, yapay çevre özellikleri, kentsel doluluklar, kentsel boşluklar ve imgesel elemanlar) ve soyut bileşenler (toplumsal özellikler: sosyal, kültürel ve ekonomik) olarak ortaya koymuştur. Çöl (1998) ise, kent kimliğinin belirleyicilerini doğal, coğrafi ve yapay çevre elemanları olarak tanımlayarak, yapay çevreyi kentin fiziksel yapısı ve mekânsal karakteristikleri olan mimari kimlik ile açıklamıştır. Bu bağlamda kent kimliğinin oluşumunda, mimari yapıların önemi büyüktür. Bu mimari yapılar içinde özellikle anıtsal değerdeki dini yapıların ayrı bir önemi vardır.

Dini yapılar; tarihsel ve anı değerleri, simgesel özellikleri, mimari karakteristikleriyle kent kimliğini oluşturan önemli bir yapı grubudur. Bu yapılar konumları, biçimsel özellikleri ve üsluplarıyla kent dokusunda diğer yapılardan farklılaşarak öne çıkmaktadır. Dini yapılar kent dokusunda stratejik noktalarda bir odak konumunda olabileceği gibi kentlerin siluetinde de işaret öğesi olabilirler. İstanbul'daki Süleymaniye Camii ve Sultanahmet Camii, Edirne'deki Selimiye Camii, Köln'deki Köln Katedrali veya Vatikan'daki St. Pierre Katedrali bu duruma örnek verilebilir (Şekil 1). 


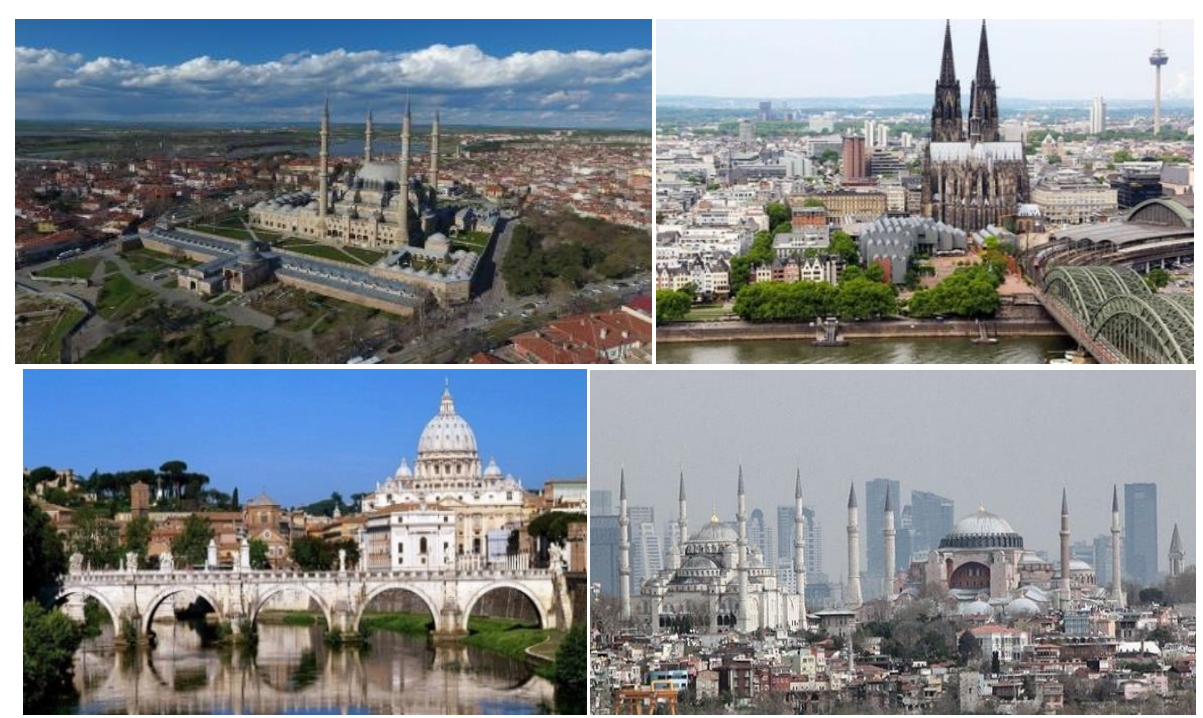

Şekil 1. Selimiye Camii/Edirne, Köln Katedrali/Köln, St. Pierre Katedrali/Vatikan, Süleymaniye Camii ve Ayasofya/İstanbul ("Anadolu Ajansı", 2018a; "Anadolu Ajansı", 2018b; “HD Wallpaper", 2019; “Sultan Ahmet Camii”, 2020).

Noktasal referans noktaları olarak işaret öğeleri, yerlerin tanınmasını diğerlerinden ayrışmasını sağlayarak kent kimliğinin oluşumunda etkili imaj öğeleri olmaktadır. İşaret öğeleri öncelikle fiziksel öğeler olmasının yanında işlevsel ve anlamsal öğelerdirler. Bu öğelerin en önemli fiziksel özelliği, bağlam içinde kolay hatırlanan güçlü şekil etkisi olan yapılar olmalarıdır. Yani bir yapının işaret öğesi olması için fiziksel açıdan net kolay algılanması, farklı, tek biçimlenmelerinin olması, çevrelerine egemen, görülebilirliği yüksek, çarpıcı perspektifler sunması, bir görünüp bir kaybolmayıp süreklilik gösteren bir niteliğe sahip olması gerekmektedir. İşlevsel açıdan ise yapının tek olması, zamanda ve bellekte kalıcı olması, kullanıcı için özgün bir yeri olması gerekmektedir (Appleyard, 1969; Appleyard, Lynch ve Myer, 1964; Cullen, 1961; Diker, Lynch, 1960; 2014; Rossi, 2006). Bu niteliklerin sadece birinin veya birkaçının etkili olması bir öğenin işaret öğesi olmasını sağlamaktadır (Yetim, 2019).

Dini yapılar biçimsel özellikleri gereği zaten net, farkll, tek, egemen gibi birçok fiziksel niteliği taşıyan, bunun yanında anlamsallık, simgesellik ve kalıcılık açısından güçlü yapılar olması sebebiyle işaret öğesi olma potansiyelleri yüksek yapılar olarak kent kimliği üzerinde önemli etkileri söz konusudur. Dini yapıların kentle ilişkisi ve onların kent kimliğinde etkili birer işaret öğesi olma potansiyellerinin yüksek olması savı üzerine temellen bu çalışma 
kapsamında, dini yapıların mevcut durumlarında kent bütünündeki etkisi fiziksel ve işlevsel açılardan tartışılmaktadır.

Çalışma kapsamında elde edilen sonuçların mevcut dini yapı çevrelerinde yapılacak düzenlemelerde veya yeni yapılacak dini yapının yer seçiminde veri oluşturması hedeflenmektedir. Özellikle Trabzon kentinin çekirdeğini oluşturan kent merkezinde yapılan çalışmada dini yapıların konumlarına ilişkin fiziksel ve işlevsel analizlerde Coğrafi Bilgi Sistemi (GIS) kullanılmış olup elde edilen veriler ArcMap 10.3 ve ArcScene 10.3 ile oluşturulan görseller üzerinden tartışılmıştır. Çalışma ele alınan alan ve kullanılan teknik açısindan özgündür.

\section{Dini Yapıların Konumu ve Biçimlenmesi}

Tarih boyunca inanılan varlıklar ve inanış anlayışı değişmiş olsa da tapınma amacıyla mekân üretme isteği değişmemektedir. Farklı inançlara temellenip, kilise, cami, sinagog gibi farklı isimlerle anılsalar da tüm ibadet mekanları o dinin mensupları tarafından kutsal kabul edilmektedir (Levi ve Kocher, 2012; Sargın, 2012). Dini yapılar fiziksel yapıları dışında anlamsal ve simgesel açıdan da diğer diğer yapılardan farklılaşmaktadır.

Çalışma alanı sınırları içerisinde dini yapı olarak cami, mescit ve kiliseye rastlanmış olup özellikle bu yapılar üzerinde durulmuştur. Cami; sözlük anlamında, içinde Cuma ve bayram namazları kılınan, gerektiğinde bazı dinsel törenlerin yapılabildiği büyük Müslüman mabedidir. Türkiye dışındaki İslam ülkelerinin çoğunluğunda, cuma ve bayram namazlarının kılındığı yer mescit olarak adlandırılırken, Türkiye'de mescit küçük camiler için kullanılmaktadır (Eczacıbaşı Sanat Ansiklopedisi,1997). Bazı camiler, medrese, kütüphane, çeşme, sebil, hamam, imaret, sıbyan okulu, darüşşifa, hazire, tabhane vb. gibi yapıların oluşturduğu külliye kompleksi içinde yer almaktadır (Peker, 2006; Ramazanoğlu, 2008).

Kilise kelimesi ise "birini dışarıya çağırmak, toplantıya davet etmek, toplamak" anlamındaki Grekçe "ekkaleo" fiilinden türetilen ve "topluluk" manasinda "ekklesia" tabirinden gelmektedir (İslam Ansiklopedisi, 2012). Kiliseler önceleri demokratik halk toplantılarının, daha sonra cemaat toplantılarının olduğu Hristiyan cemaatinin ibadet etmek için kullandığı yapılardır. Kısacası kilise, toplanma, ibadet etme, dinsel bayramları-ritüelleri kutlama, Tanrı uğruna ölen şehitleri anma mekanı olmaktadır (Diker, 2014). Kilise, dini mekânlar için genel olarak kullanılan bir ifade şekli olmakla birlikte günümüzde Hristiyan mabetleri şapel, bazilika, katedral gibi çeşitli isimlerle ifade edilmektedir (Marchesano, 2007). 
Biçimlenme açısından cami ve mescitlerin biçimlenişini etkileyen faktörler namaz için temel olan ihtiyaçlar doğrultusundadır. Mescitler sadece vakit namazları için kullanıldığından küçük mekânlardır. Tek kubbeli ve ya düz çatılı olarak yapılmaktadırlar. Bazı mescitlerde tek minare bulunurken bazılarında minare bulunmamaktadır. Ana mekana eklenen ikinci bir mekan giriş kısmı olarak kullanılmaktadır. Giriş kısmı kapalı ve ya yarı açık şekilde biçimlenmektedir. Camiler ise; harim bölümü ve dış avlu olmak üzere iki ana bölümden oluşmaktadır. Camilere genellikle anıtsal kapılardan veya taç kapılardan girilmektedir. Caminin dış avlusuna açılan cami kapıları bulunmaktadır. Caminin Kâbe'ye yönelmesinden dolayı kent dokusuna açlı bir yerleşimi söz konusudur. Bu nedenle camilerin önünde genellikle genişleyen sokaklar bulunmaktadır. Sokaktan, bir duvarla ayrılan caminin avlusuna girilmektedir. Dış avlu genellikle, pencereleri demir parmaklıklarla süslü bir alçak duvarla çevrilidir. Avluda abdest alma ihtiyacını karşılayan şadırvan bulunmaktadır. Caminin girişinde revak diye adlandırılan üstü kapalı yarı açık iç avlu olarak adlandırılan bir alan bulunmaktadır. Harim bölümü; mihrap, minber, vaiz kürsüsü ve dikdörtgen oylumun üzerini örten kubbe ve yan kubbelerden meydana gelmektedir. Son cemaat yeri esas caminin giriş kapısı olan yüzünde bulunmaktadır. Minareler ise esas caminin dış duvarlarına ya da iç avlu duvarlarına bağlanmaktadır (Akbulut ve Erarslan, 2017; Akın, 2016; Diker, 2014; Öz, 2013; Sarıhan, 2015;) (Şekil 2).
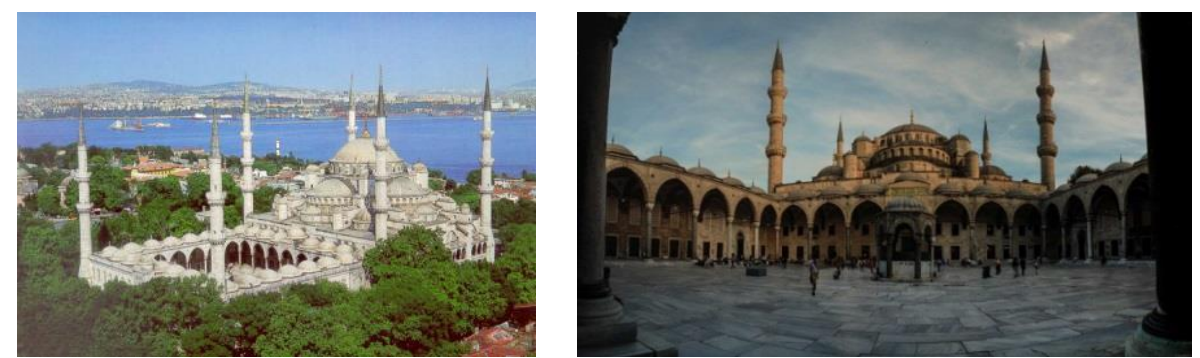

Şekil 2. Sultanahmet Camii/İstanbul ("Çamlıca Camii", 2020; "Sultan Ahmet Camii Bilinmeyenleri", 2020c).

Hristiyanların 4. Yy'in sonlarına doğru toplu ibadet için özel mimari birimler inşa ettiği bilinmektedir. Kiliseler de camiler gibi özel bir yöne doğuya doğru yönlenmektedir. Kiliselere giriş batı yönünde yapılmakta burada büyük bir ön avlu (atriyum) bulunmaktadır. Bazı kiliselerde 3 ya da 4 tarafı arkad ile çevrili atriyumun olduğu ayinden önce cemaatin burada toplandığ 1 belirtilmektedir. Bu mekan peribolos adı verilen duvarlar ile kutsal alanı dünyevi çevreden ayırmaktadır. Atrium içerisinde çeşmeler bulunmaktadır. Bu 
çeşmelere krene, phiale ve ya kantharos adı verilmektedir. Bazı kiliselerde ana mekânın girişinin önünde bazen tek bazen çift Nartheks adı verilen kapalı bir hol düzenlenebilmektedir. Narteksten naosa girişi sağlayan iki sütün ve üç kemerden oluşan trivelon adı verilen anıtsal bir giriş bulunmaktadır (Eczacıbaşı Sanat Ansiklopedisi, 1997; İslam Ansiklopedisi, 2012; Atıc1, 2018; Erbilgin, 2017; Erdem ve İnce, 2016; Nuroğlu, 2014;). Kilise mimarisinin diş elemanlarındaki baskın öğeleri; çan kuleleri, kubbeler ve sivri kulelerdir. Kubbe ve sivri kuleler siluette kiliseleri belli eden yapı parçalarıdır. Çan kuleleri kilisenin yanında ve ya bitişik konumda bulunan içinde çanların yer aldığı konik ve ya piramit biçimli yapılardır (Kostaf, 1993; Kuban, 2010; Mango, 2006) (Şekil 3).
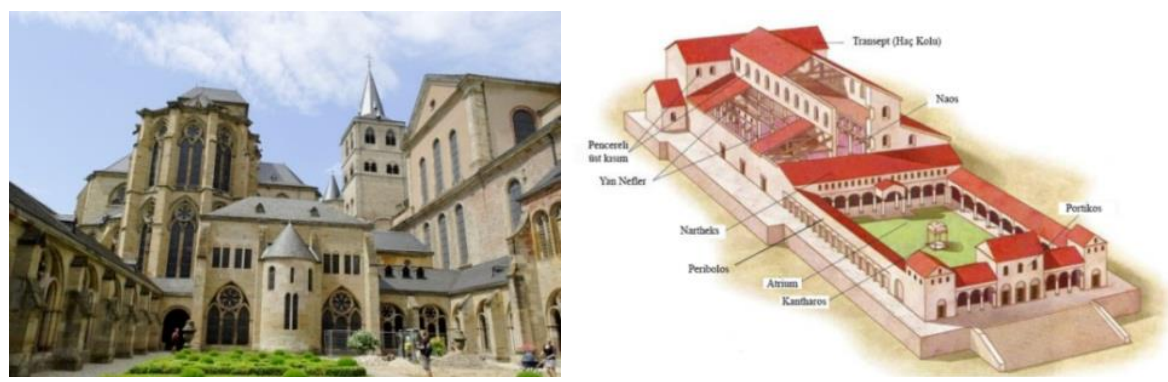

Şekil 3. Trier Katedrali/Trier (“Wescott”, 2018).

\section{Yöntem}

Dini yapıların işaret öğesi olma potansiyellerinden dolayı kent kimliği üzerinde etkileri olduğu savı üzerine temellenen bu çalışmanın temel amacı Trabzon' daki dini yapıların kentle ilişkisini, kent kimliği veya kent imajı üzerindeki etkilerini irdelemektir. Bu amaçla fiziksel ve işlevsel analizler yapılmıştır. Böylece Trabzon kent merkezinde yer alan kentin kimliğindeki etkili dini yapılar ortaya konmuştur.

Bu amaçla çalışmanın varsayımları fiziksel açıdan;

- Dini yapılar, kent dokusunda ve/veya kent siluetinde özgün biçimleri, boyutsal farklılıkları ile çevresine egemen ve çevresinde tek olması sonucu öne çıkmaktadır. Dolayısıyla bu yapıların algılanabilirlikleri güçlü, işaret öğesi olma potansiyelleri de yüksek olmaktadır.

- Topografik açıdan dağlık olan kentin yüksek noktalarında yer alan dini yapıların görülebilirlikleri fazla olmaktadır. Bu durum bir taraftan dini yapının güçlü bağlamla çarpıcı olmasına diğer taraftan hem kent içinde hem 
de kent siluetinde öne çıkmasını sağlayarak işaret öğesi olma potansiyelini arttırmaktadır.

- Sosyal hayatın aktığı ve kentin yoğun kullanılan kent odaklarında ve/veya kentin önemli arterlerini oluşturan yollar üzerinde yer alan veya bu yollardan algılanan dini yapıların işaret öğesi olma potansiyelleri yüksek olmaktadır.

- Dini yapılar biçimsel açıdan genellikle kapalı, açık ve yarı açık mekânlardan oluşmaktadır. Bu mekânsal hiyerarşi ve odak, vadi gibi geniş boşlukların içinde veya yakınında olma dini yapının algılanmasını güçlendirerek işaret öğesi olma potansiyelini arttırmaktadır.

- Kalıcılık, bir yapının işaret öğesi olması için sahip olması gereken önemli bir özellik olmaktadır. Dini yapılar anlamsal, simgesel ve kalıcılık değerleri yüksek yapılardır. Bu yapıların zamanda süreklilik göstermesi işaret öğesi olma potansiyellerini arttırmaktadır.

İşlevsel açıdan;

- Dini yapının konumlandığı yerleşim alanı içerisinde tek dini yapı olması ve geniş bir alana hizmet etmesi dini yapının işaret öğesi olma potansiyelini arttırmaktadır.

- Erişim mesafesi içinde birden çok dini yapının olması kullanıcının dikkatinin dağılmasına neden olmaktadır. Dolayısıyla erişim mesafesi içinde tek olan dini yapıların işaret öğesi olma potansiyelleri yüksek olmaktadır.

şeklinde oluşturulmuştur.

Bu varsayımlardan yola çıkılarak ilk olarak işaret öğesinin fiziksel açıdan taşıdığı farklı/tek olma, egemen olma, görünür olma ve çarpıcı perspektifler sunma nitelikleri temel alınmıştır. Bu özellikler kent topografyası, kent dokusu, kent silueti üzerinde tartışılmıştır. Buna ek olarak kentsel imaj öğelerinin birbirini destekleyen bütünsel etkisi nedeniyle dini yapıların kent odakları ve yollarla ilişkileri de incelenmiştir.

İkinci olarak bu dini yapıların işlevsel ilişkilerini, tek olma özelliklerini ortaya koymak üzere, mahalle ölçeğinde hizmet alanı ve erişilebilirlik analizleri ile kullanım yoğunluğu üzerinden işaret öğesi olma potansiyelleri ortaya konmuştur.

Erişim mesafeleri, dini yapıların türüne göre çeşitlilik göstermektedir. Bu mesafe küçük dini yapılarda $250 \mathrm{~m}$ ve büyük dini yapılarda $400 \mathrm{~m}$ olarak belirlenmiştir (Çevre ve Şehircilik Bakanlığı, 2019). Çalışmada mescit ve tekke olan dini yapılar küçük dini yapılar, cami ve kilise olan dini yapı ise büyük dini yapı olarak kabul edilmiştir. Ayrıca; dönüştürülen ve ya yıkılıp yerine 
başka dini yapı yapılan yapılarda dönüşümden ve ya yıkımdan önceki yapı türü dikkate alınmıştır (Şekil 4).

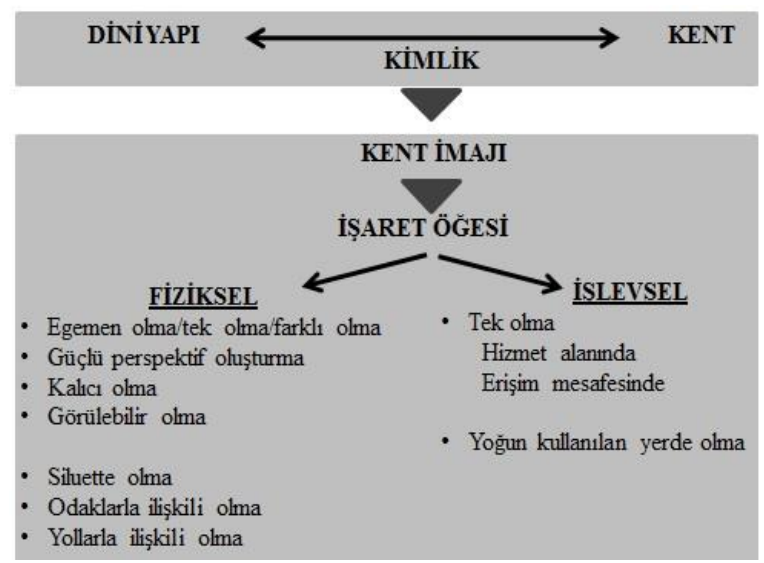

Şekil 4. Dini yapı - kent kimliği ilişkisi.

Bu analizlerde GIS (Coğrafi Bilgi Sistemi) üzerinden iki boyutlu modelleri oluşturmada ArcMap 10.3 ve verilerin üç boyutlu modelleri için ArcScene 10.3 kullanılmıştır. Gelişmiş/gelişmekte olan ülkelerin kent planlaması açısından oldukça çok kullanılan veri tabanı odaklı bir sistem olarak GIS, mekânsal ve metinsel verileri coğrafi bir model olarak depolamakta, sonrasında bu verileri kullanarak çeşitli modellemeler ve analizler yapma seçeneği sunmaktadır. Coğrafi Bilgi Sistemi (GIS) kullanımı birçok alanda ve farklı çalışmalarda kullanılan bir yöntemdir. Milne ve Sear'ın 1997 yılında yaptığı "Modelling River Channel Topography Using GIS" isimli çalışmasında kentteki nehir havzalarının üç boyutlu tespiti için topografik parametrelere bağlı olarak oluşturulan TIN veri yapıları olarak tanımlanan sayısal yükseklik modeli üretmişlerdir. Park'ın 2012 yılında yaptığı “Measuring Public Library Accessibility: A Case Study Using GIS" isimli çalışmasında iki nokta arasındaki uzaklığı daha gerçekçi verilerle tespit etmek için kentsel ölçekte binalar arasındaki gerçek uzaklıkları GIS kullanarak tespit etmiş ve bu binalar arasındaki erişilebilirlik analizlerini yapmıştır. Çetin' in 2015 yılında yaptığı “Using GIS Analysis to Assess Urban Green Space in Terms of Accesibility: Case Study in Kütahya" isimli çalışmasında iki nokta arasındaki uzaklı̆̆ı tespit etmek için kentteki yeşil alanlara uzaklıkları ve erişim durumunu GIS kullanarak tespit etmiştir. Çalışma kapsamında GIS, koordinat sistemine göre yollar, binalar ve mahalle sınırları, işlev çeşitliliği, kullanım yoğunluğunun tespitinin yanı sıra, hem yatay hem de yükseklik olarak mesafe ölçümleri ve yapılan 
analizlerin görselleştirilmesi için kullanılmıştır. ArcMap 10.3 ve ArcScene 10.3 kullanılarak iki boyutlu ve üç boyutlu modellere dönüştürülmüştür.

Çalışma coğrafi konumu nedeniyle tarihin her döneminde farklı topluluk ve medeniyetlerin egemenlik kurduğu stratejik bir liman kenti olan Trabzon kent merkezinde yapılmıştır. Trabzon kentinin dağlık ve vadilerden oluşan topografik yapısı sonucu ulaşım yatayda ve vadiler boyunca uzanan dikey yollarla sağlanmıştır. Lineer uzanan kent yapısında Tanjant Yolu, Devlet Sahil Yolu ve 2. Sahil Yolu ana yatay ulaşım aksları olmaktadır.

Kent merkezinde ise Tabakhane, Uzunsokak, Kunduracilar Caddesi, Kemeraltı ve Kahramanmaraş Caddesi yoğun kullanılan yatay ulaşım aksları olmaktadır. Ayrıca Kavak Meydanı, Sakız Meydanı, Atapark, Atatürk Alanı ve Güzelhisar Meydanı olmak üzere toplamda 5 odak yer almaktadır (Doğan, 2016; Kalın, 2004). Fakat bunlardan sadece Atapark ve Atatürk Alanı meydan işlevini sürdürmektedir (Şekil 5).

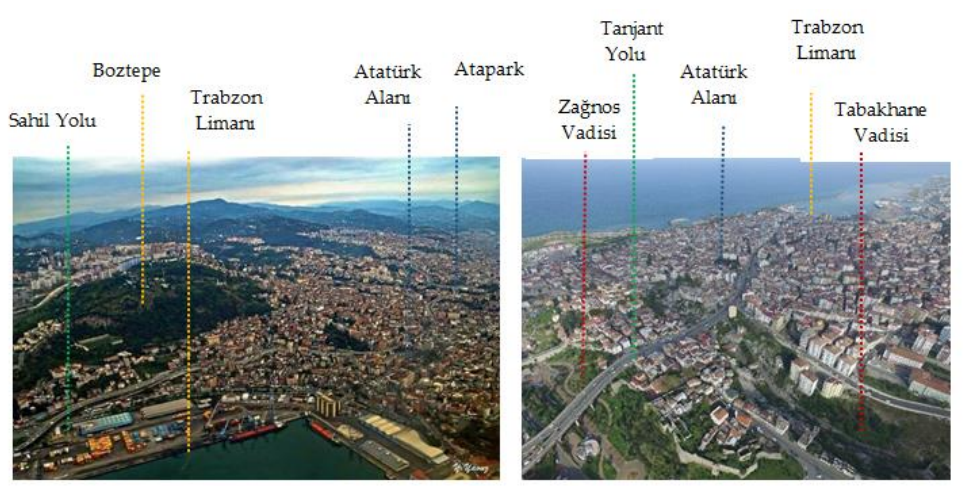

Şekil 5. Trabzon kenti (“Emlak Haber Ajansı”, 2020; “Trabzon Haberleri”, 2016).

Çalışma alanı sınırı, Trabzon Kent İçi Kültür Varlıkları Envanteri (2010)'nde yer alan "kent içi cami dağılımı" harita sınırları temel alınarak belirlenmiştir. Toplamda 22 mahalle ve 33 dini yapı tespit edilmiştir. Bu dini yapılardan 9'u cami 2' si kilisedir. Bunların dişında 11'i mescitten, 5' i kiliseden ve 1'i tekkeden camiye dönüştürülmüştür. 5 mescit yapısı ise yıkılarak yerine cami inşa edilmiştir (Özen vd., 2010). Bu yapılardan Erdoğdu Merkez Camii (H3), Mehmet Akif Ersoy Camii (H10) ve Yeni Hal Camii (H24) dışındaki dini yapıların tümü koruma altına alınmış birinci derece anıtsal yapılardır (Şekil $6)$. 


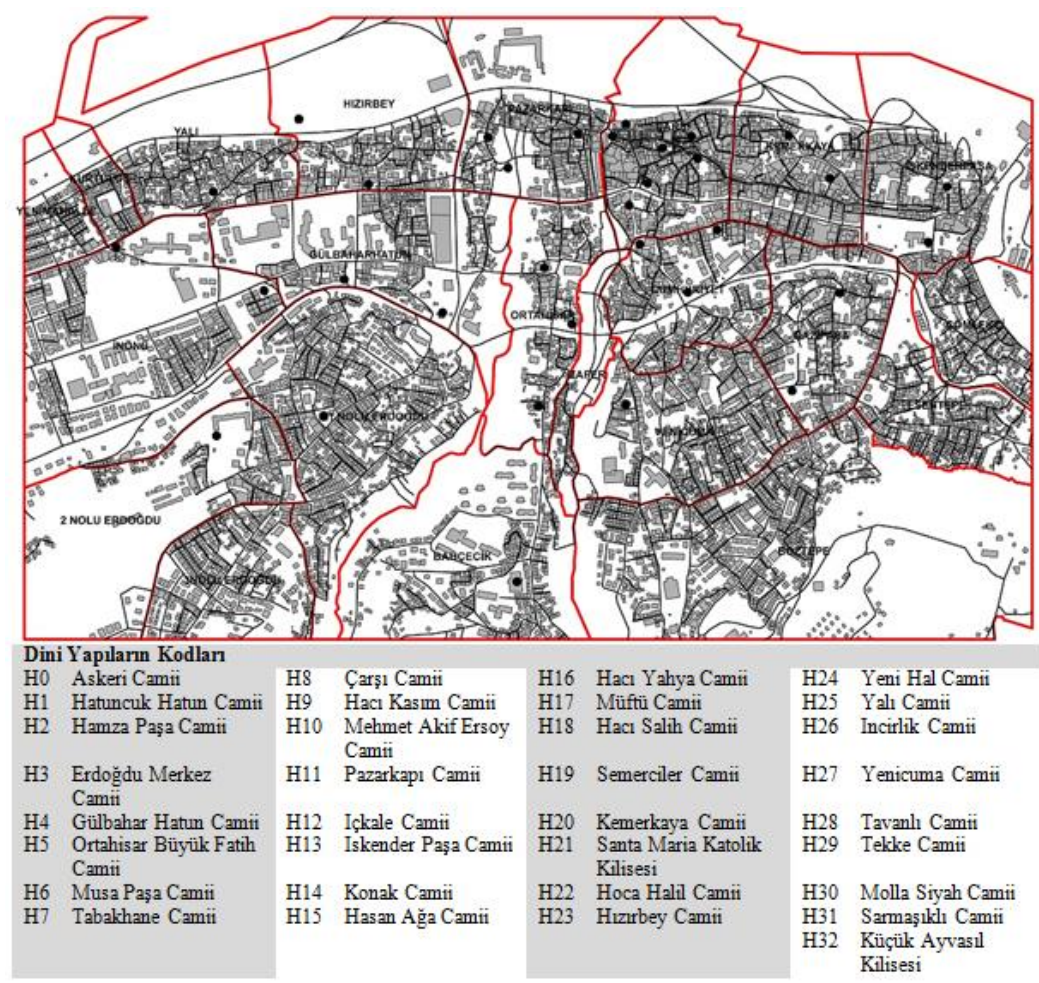

Şekil 6. Çalışma alanı sınırı.

\section{Bulgular}

Dini yapının kentle kurduğu ilişki fiziksel ve işlevsel açıdan irdelenmiştir. Yapılan fiziksel analizler kent topografyası, kent dokusu, kent silueti, kent odakları ve yollarıyla ilişkisi üzerinde tartışılmıştır.

\section{Fiziksel Açıdan}

Kent Topografyasında: Her bir dini yapının deniz seviyesine göre yüksekliği tespit edildiğinde; kentin en yüksek noktasında 125 -150m yüksekliğinde Mehmet Akif Ersoy Camii (H10) konumlanmıştır. Bu yapının konumu gereği kente görülebilirliğinin yüksek ve kent siluetinde etkili olması beklenirken çarpık ve yoğun yapılaşma nedeniyle kent siluetinde görülememektedir. Ayrıca Mehmet Akif Ersoy Camii (H10)'den sonra kentin 75 -125m yüksekte konumlanan Askeri Camii (H0), Erdoğdu Merkez Camii (H3) ve Tekke Camii (H29) de yine kent siluetinde görülememektedir. Tüm bu yapılar topografyanın sunduğu işaret öğesi olma potansiyellerini kullanamamışlardır (Şekil 7). 


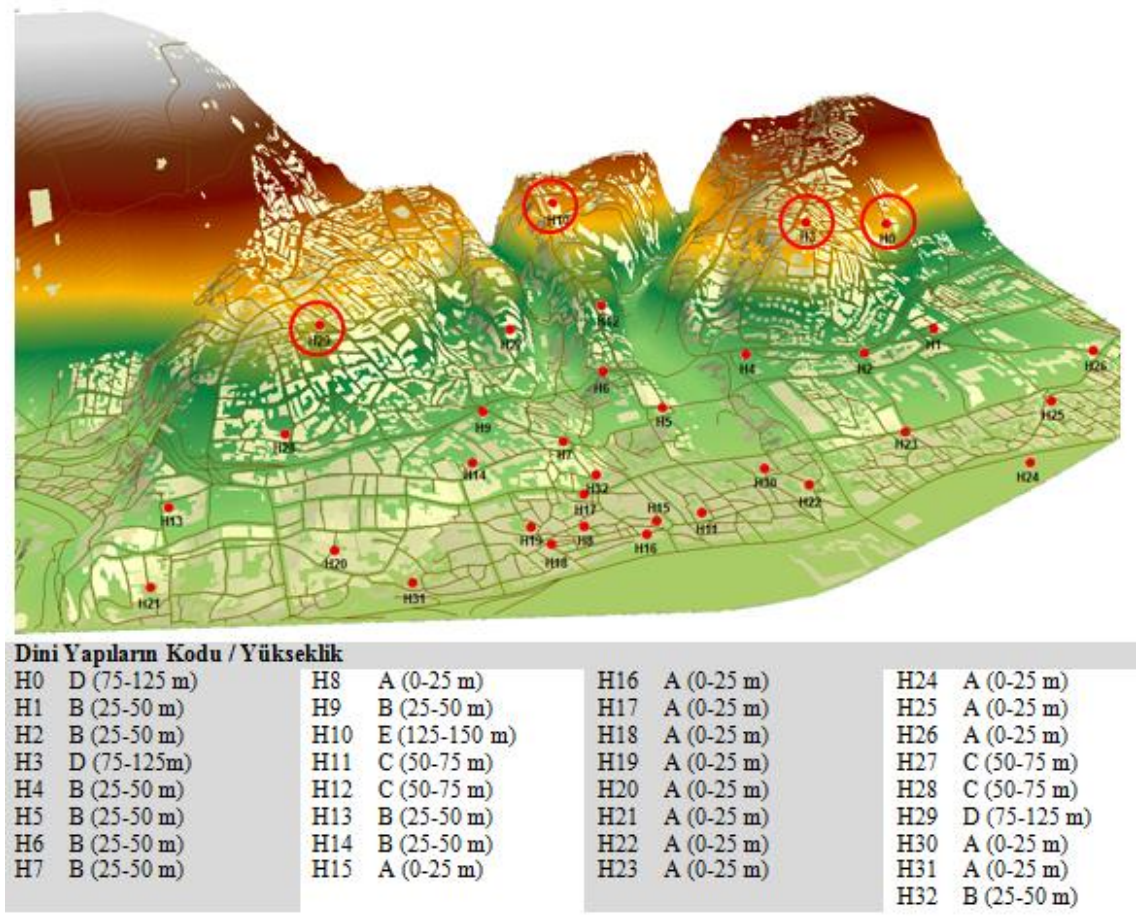

Şekil 7. Topografya analizi.

\section{Kent Dokusundaki Yeri:}

- Yoğun yapılaşma içinde kalan Erdoğdu Merkez Camii (H3) ve Çarşı Camii (H8) avlulu yapıları gereği oluşturduğu boşluk sonucunda çevrelerinde tektir, bu durum işaret öğesi olma potansiyellerini arttırmaktadır. Erdoğdu Merkez Camii (H3), Gülbahar Hatun Camii (H4), Ortahisar Büyük Fatih Camii (H5), Musa Paşa Camii (H6), Çarşı Camii (H8), Hacı Kasım Camii (H9), Mehmet Akif Ersoy Camii (H10), Pazarkapı Camii (H11), Hasan Ağa Camii (H15), Hacı Yahya Camii (H16), Müftü Camii (H17), Semerciler Camii (H19), Hızırbey Camii (H23), Yenicuma Camii (H27) ve Tekke Camii (H29) çevresindeki yapılaşmadan daha yüksek olmaları çevrelerine hem boyutsal olarak egemen hem de görülebilir olması nedeniyle işaret öğesi olma potansiyelleri yüksektir (Şekil 8). 


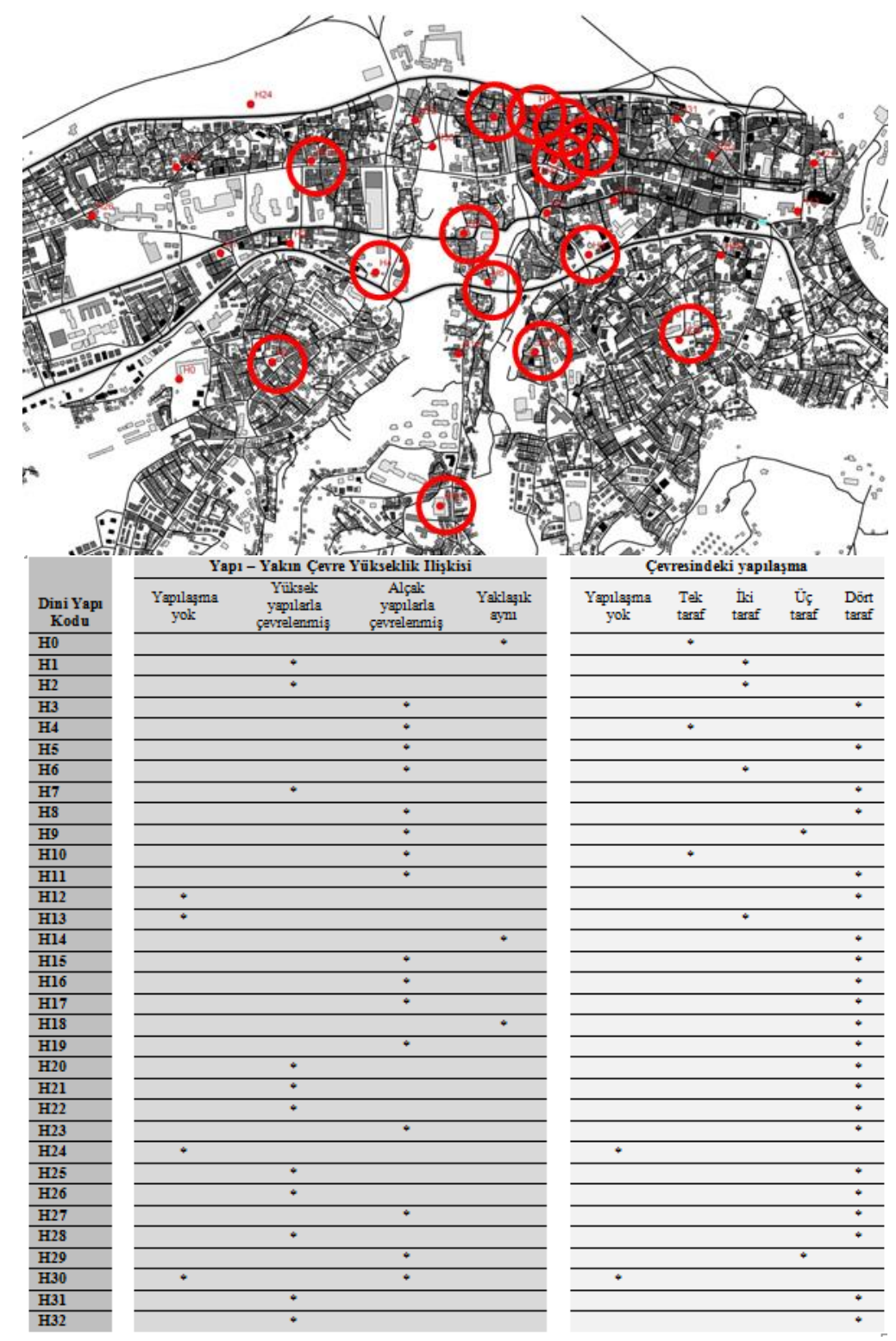

Şekil 8. Yoğunluk, kat adedi ve kapalılık analizi.

-Gülbahar Hatun Camii (H4) Atapark ve İskender Paşa Camii (H13) ise Atatürk Alanı ile yani odakla buluşmaları sonucu boşluk etkisiyle geniş bir perspektiften algilanmaktadır.

-Hatuncuk Hatun Camii (H1), Erdoğdu Merkez Camii (H3), Gülbahar Hatun Camii (H4), Ortahisar Büyük Fatih Camii (H5), Hacı Kasım Camii 
(H9), Mehmet Akif Ersoy Camii (H10), İskender Paşa Camii (H13) ve Müftü Camii (H17) yapıları avlulu olmaları ve açık, yarı açık , kapalı mekânlardan oluşan biçimlenmeleri sonucu boşluk etkisiyle geniş bir perspektiften algılanmaktadır.

-Askeri Camii (H0), Hatuncuk Hatun Camii (H1), Hamza Paşa Camii (H2), Hızırbey Camii (H23), Yalı Camii (H25) ve İncirlik Camii (H26) yakın çevresinde geniş avlulu yapıların ve Ortahisar Büyük Fatih Camii (H5), Tabakhane Camii (H7), Mehmet Akif Ersoy Camii (H10) ve Yeni Cuma Camii (H27) ise yanında vadilerin bulunması sonucu boşluk etkisiyle geniş bir perspektiften algılanmaktadır. Tüm bunlar bu dini yapıların işaret öğesi olma potansiyellerini arttırmaktadır (Şekil 9).
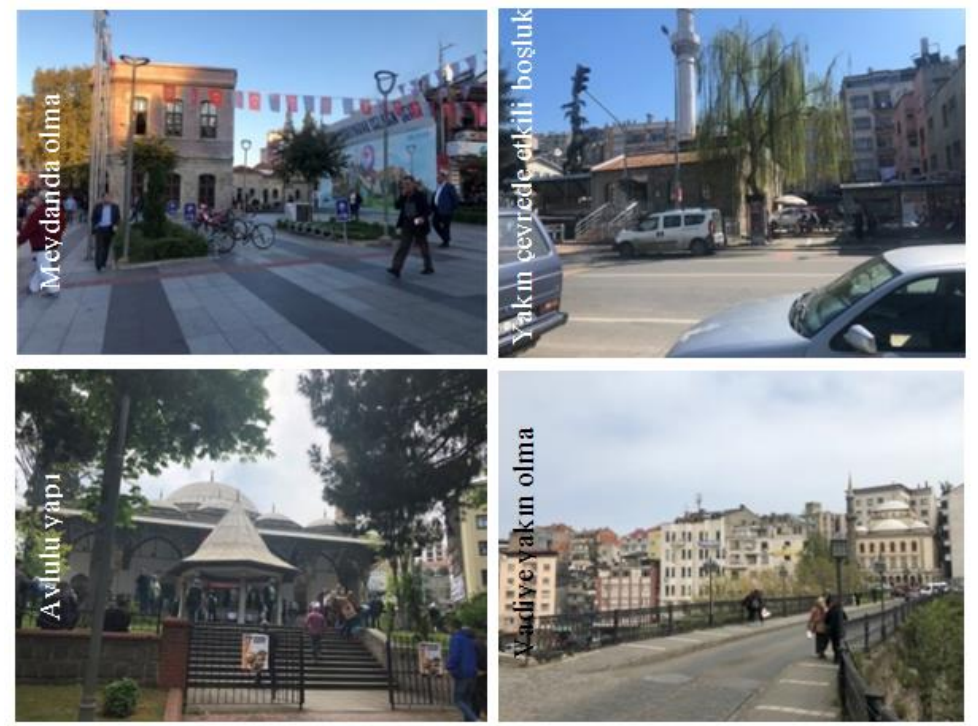

Şekil 9. Dini yapıların algılanması (Yazarlar tarafından çekilmiştir.).

Kent Siluetinde: Çarşı Camii (H8), Pazarkapı Camii (H11), Yeni Hal Camii (H24) ve Yalı Camii (H25) Devlet Sahil Yolu'ndan görünen kentin siluetinde yer alan dini yapılar olmaktadırlar. Bu açıdan işaret öğesi olma potansiyelleri yüksek olmasına rağmen etraflarındaki yoğun, yüksek ve çarpık yapılaşma nedeniyle görülebilirlikleri ve siluetteki etkileri zayıftır. Bu nedenle işaret öğesi olarak potansiyellerini kullanamamışlardır (Şekil 10). 

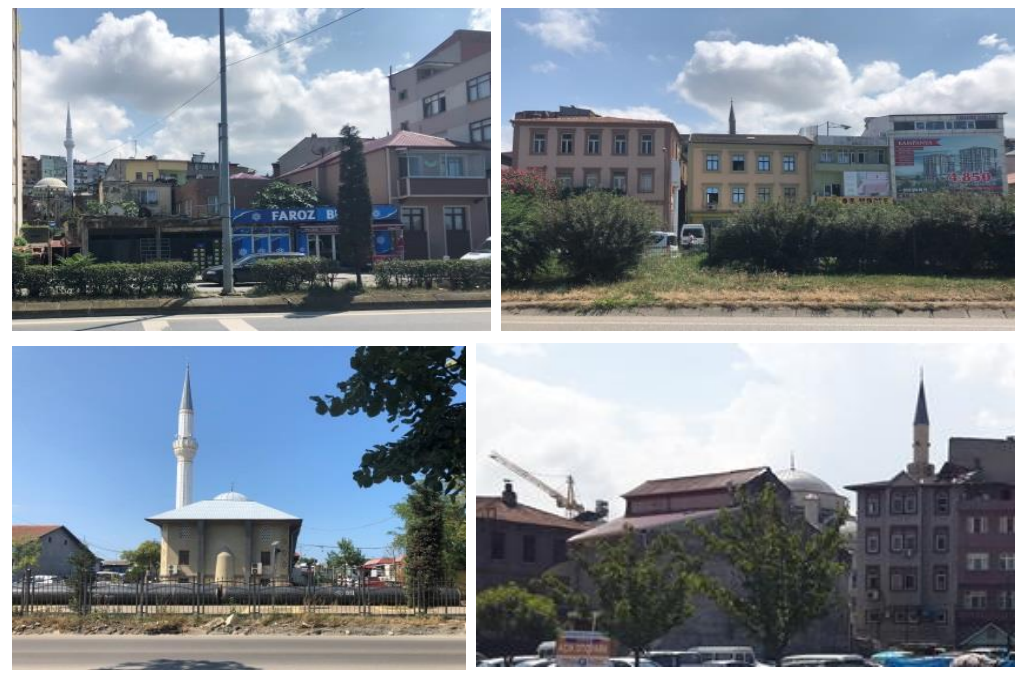

Şekil 10. Yalı Camii/H25, Çarşı Camii/H8, Yeni Hal Camii/H24,

Pazarkapı Camii/H11 (Yazarlar tarafından çekilmiştir.).

Kent Odaklarıla İlişkisi: Kent merkezinde yer alan kentin halen etkili biçimde kullanılan iki önemli odağı; Atapark ve Atatürk Alanıdır. Atapark' ta yer alan Gülbahar Hatun Camii (H4) ve Atatürk Alanı' nda yer alan İskender Paşa Camii (H13) sürekli göz önünde olma açısından işaret öğesi olma potansiyeli yüksek yapılardır (Şekil 11).
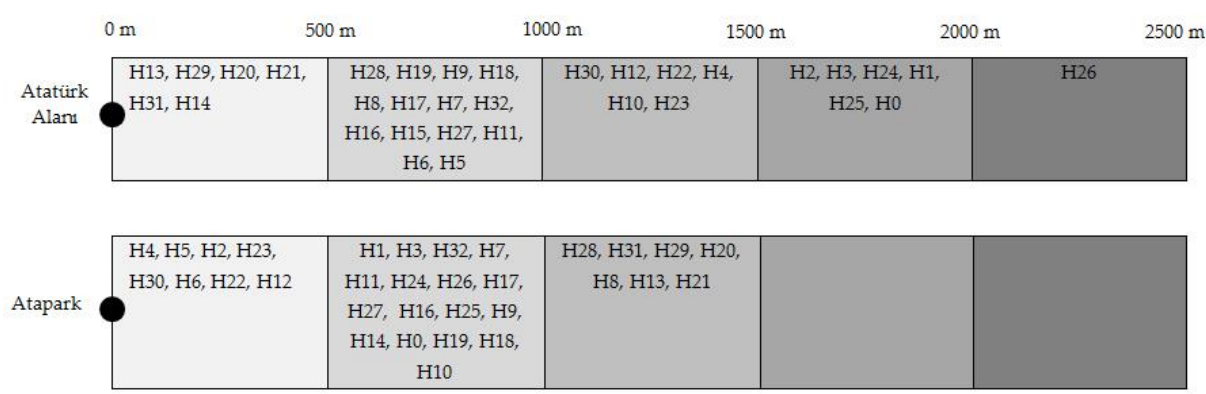

Şekil 11. Dini yapıların Atapark' a ve Atatürk Alanı' na uzaklığı.

Yolla ilişkisi: Çalışma alanı içinde Tanjant Yolu, Devlet Sahil Yolu, Uzunsokak İnönü Yolu, Kunduracılar Kemeraltı Yolu ve Kahramanmaraş Caddesi yoğun olarak kullanılan yatay yollardır. Bu yollardan Tanjant Yolu üzerinde Hamza Paşa Camii (H2), Gülbahar Hatun Camii (H4), Musa Paşa Camii (H6) ve Hacı Kasım Camii (H9), Devlet Sahil Yolu üzerinde Yeni Hal Camii (H24), Uzunsokak İnönü Yolu üzerinde Hatuncuk Hatun Camii (H1), 
Ortahisar Büyük Fatih Camii (H5), Tabakhane Camii (H7), İskender Paşa Camii (H13) ve Konak Camii (H14), Kunduracılar Kemeraltı Yolu üzerinde Çarşı Camii (H8) ve Semerciler Camii (H19), Kahramanmaraş Caddesi üzerinde ise Müftü Camii (H17), Hızırbey Camii (H23) ve İncirlik Camii (H26) dini yapıları yer almaktadır. Fakat yol üzerinde olan bu dini yapılar arasından da sadece Hatuncuk Hatun Camii (H1), Ortahisar Büyük Fatih Camii (H5), Tabakhane Camii (H7), Çarşı Camii (H8), Konak Camii (H14), Semerciler Camii (H19), Yeni Hal Camii (H24) ve İncirlik Camii (H26) yol kotunda ya da yol kotunun üstünde konumlanmıştır. Dolayısıyla işaret öğesi olma potansiyeli yüksektir.

Kalıcılıkla ilişkisi: Erdoğdu Merkez Camii (H3), Mehmet Akif Ersoy Camii (H10) ve Yeni Hal Camii (H24) dişındaki dini yapılar koruma altına alınmış birinci derece anıtsal yapılar olarak kalıcı yapılar olmaktadır. Fakat yapılan arşiv çalışması ve elde edilen eski fotoğraflar sonucunda bu yapılardan sadece \%9' unda Askeri Cami (H0), Çarşı Cami (H8), Santa Maria Katolik Kilisesi (H21) ve Küçük Ayvasıl Kilisesi (H32) değişim olmamıştır.

\section{İşlevsel Açıdan}

35,35 hektar 1 Nolu Erdoğdu Mahallesine hizmet eden Erdoğdu Merkez Camii (H3), 29,47 hektar olan Bahçecik Mahallesine hizmet eden Mehmet Akif Ersoy Camii (H10), 28,29 hektar olan 2 Nolu Erdoğdu Mahallesine hizmet eden Askeri Camii (H0), 21,58 hektar olan Yalı Mahallesine hizmet eden Yalı Camii (H25), 21,27 hektar olan Yeni Cuma Mahallesine hizmet eden Yeni Cuma Camii (H27) yer aldıkları mahallede tek dini yapı olarak işaret öğesi olma potansiyelleri yüksek olmaktadır. Askeri Camii (H0), Erdoğdu Merkez Camii (H3), Mehmet Akif Ersoy Camii (H10), Hızırbey Camii (H23), Yalı Camii (H25), İncirlik Camii (H26) ise erişim mesafesi içinde tek dini yapı olduklarından işaret öğesi olma potansiyelleri yüksek olmaktadır (Şekil 12). 


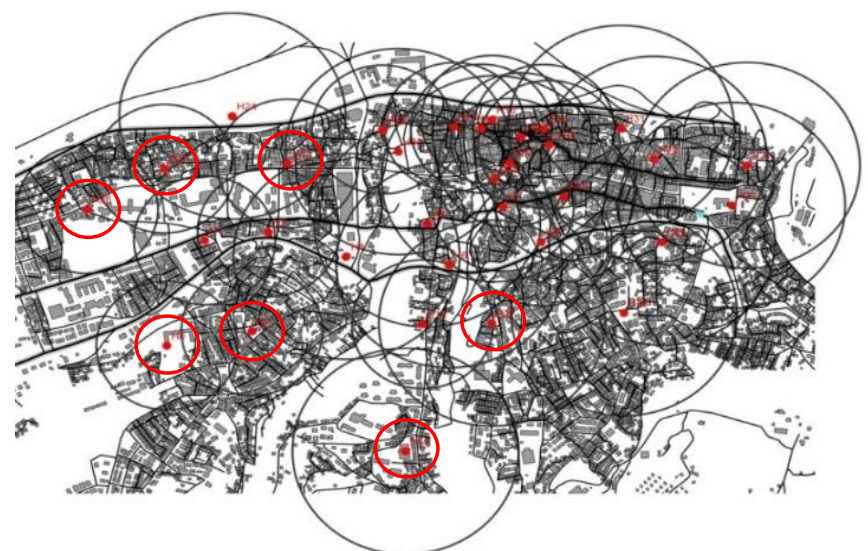

\begin{tabular}{|c|c|c|c|}
\hline $\begin{array}{l}\text { Dini } \\
\text { Yap1 }\end{array}$ & Bulunduğu Mahalle & Hizmet Alanındaki Dini Yapılar & Erişim Mesafesindeki Dini Yapılar \\
\hline HO & 2 Nolu Erdoğdu & - & - \\
\hline H1 & İnönü & $\mathrm{H} 26$ & $\mathrm{H} 2$ \\
\hline $\mathrm{H} 2$ & Gülbahar Hatun & $\mathrm{H} 4$ & $\mathrm{H} 1$ \\
\hline H3 & 1 Nolu Erdoğdu & - & - \\
\hline $\mathrm{H} 4$ & Gülbahar Hatun & $\mathrm{H} 2$ & $\mathrm{H} 2-\mathrm{H} 5-\mathrm{H} 6-\mathrm{H} 12$ \\
\hline H5 & Ortahisar & H6-H12 & $\begin{array}{l}\text { H4-H6-H7-H11-H12-H17-H22-H30- } \\
\text { H32 }\end{array}$ \\
\hline H6 & Ortahisar & H5-H12 & H4-H5-H7-H9-H12-H27-H32 \\
\hline H7 & Cumhuriyet & H9-H14 & H9-H14-H17-H32 \\
\hline H8 & Çarşı & H15-H16-H17-H18-H19-H32 & H11-H15-H16-H17-H18-H19-H32 \\
\hline H9 & Cumhuriyet & H7-H14 & H7-H14 \\
\hline H10 & Bahçecik & - & - \\
\hline H11 & Pazarkapı & $\mathrm{H} 22-\mathrm{H} 30$ & $\mathrm{H} 22-\mathrm{H} 30$ \\
\hline H12 & Ortahisar & H5-H6 & $\mathrm{H} 27$ \\
\hline H13 & İskender Paşa & $\mathrm{H} 21$ & $\mathrm{H} 20-\mathrm{H} 21-\mathrm{H} 29$ \\
\hline H14 & Cumhuriyet & $\mathrm{H} 7-\mathrm{H} 9$ & H7-H9-H17-H19 \\
\hline H15 & Çarşı & H8-H16-H17-H18-H19-H32 & H8-H11-H16-H17-H18-H19-H32 \\
\hline H16 & Çarşı & H8-H15-H17-H18-H19-H32 & H8-H11-H15-H17-H18-H19-H32 \\
\hline H17 & Çarşı & H8-H15-H16-H18-H19-H32 & H8-H11-H15-H16-H18-H19-H32 \\
\hline H18 & Çarş1 & H8-H15-H16-H17-H19-H32 & H8-H11-H15-H16-H17-H19-H32 \\
\hline H19 & Çarş1 & H8-H15-H16-H17-H18-H32 & H8-H11-H15-H16-H17-H18-H32 \\
\hline $\mathrm{H} 20$ & Kemerkaya & $\mathrm{H} 31$ & H13-H14-H19-H21-H29-H31 \\
\hline $\mathrm{H} 21$ & İskender Paşa & $\mathrm{H} 13$ & $\mathrm{H} 13-\mathrm{H} 20$ \\
\hline $\mathrm{H} 22$ & Pazarkapı & $\mathrm{H} 11-\mathrm{H} 30$ & $\mathrm{H} 11-\mathrm{H} 30$ \\
\hline $\mathrm{H} 23$ & Hızırbey & $\mathrm{H} 24$ & - \\
\hline $\mathrm{H} 24$ & Hızırbey & $\mathrm{H} 23$ & $\mathrm{H} 23-\mathrm{H} 25$ \\
\hline $\mathrm{H} 25$ & Yalı & - & - \\
\hline $\mathrm{H} 26$ & İnönü & $\mathrm{H} 1$ & - \\
\hline $\mathrm{H} 27$ & Yenicuma & - & H6-H9-H12 \\
\hline $\mathrm{H} 28$ & Gazipaşa & $\mathrm{H} 29$ & $\mathrm{H} 9-\mathrm{H} 29$ \\
\hline $\mathrm{H} 29$ & Gazipaşa & $\mathrm{H} 28$ & H13-H14-H20-H28 \\
\hline H30 & Pazarkapı & $\mathrm{H} 11-\mathrm{H} 22$ & $\begin{array}{l}\text { H5-H8-H11-H15-H16-H17-H22-H23- } \\
\text { H32 }\end{array}$ \\
\hline H31 & Kemerkaya & $\mathrm{H} 20$ & H8-H14-H18-H19-H20 \\
\hline H32 & Çarşı & H8-H15-H16-H17-H18-H19 & $\begin{array}{l}\text { H5-H6-H7-H8-H9-H11-H14-H15- } \\
\text { H16-H17-H18-H19-H30 }\end{array}$ \\
\hline
\end{tabular}

Şekil 12. Erişilebilirlik analizi. 
-Hatuncuk Hatun Camii (H1), Gülbahar Hatun Camii (H4), İskender Paşa Camii (H13), Konak Camii (H14), Hızırbey Camii (H23), Yalı Camii (H25), Yeni Cuma Camii (H27) ve Sarmaşıklı Camii (H31) çevresinde farklı işlevler barındırması sonucu yoğun kullanılmakta işaret öğesi olma potansiyelleri yüksek olmaktadır.

-Askeri Camii (H0), Hatuncuk Hatun Camii (H1), Hamza Paşa Camii (H2), Gülbahar Hatun Camii (H4), Ortahisar Büyük Fatih Camii (H5), Tabakhane Camii (H7), Hacı Kasım Camii (H9), Mehmet Akif Ersoy Camii (H10), Pazarkapı Camii (H11), İskender Paşa Camii (H13), Konak Camii (H14), Müftü Camii (H17), Kemerkaya Camii (H20), Hızırbey Camii (H23), Yeni Hal Camii (H24), Yalı Camii (H25), İncirlik Camii (H26), Yeni Cuma Camii (H27), Tavanlı Camii (H28), Sarmaşıklı Camii (H31) ve Küçük Ayvasıl Kilisesi (H32) ise yoğun kullanılan eğitim, sağlık, resmi kurum, ticaret yapılarının yakınında olmaları sonucu yoğun kullanılmakta işaret öğesi olma potansiyelleri yüksek olmaktadır (Şekil 13).

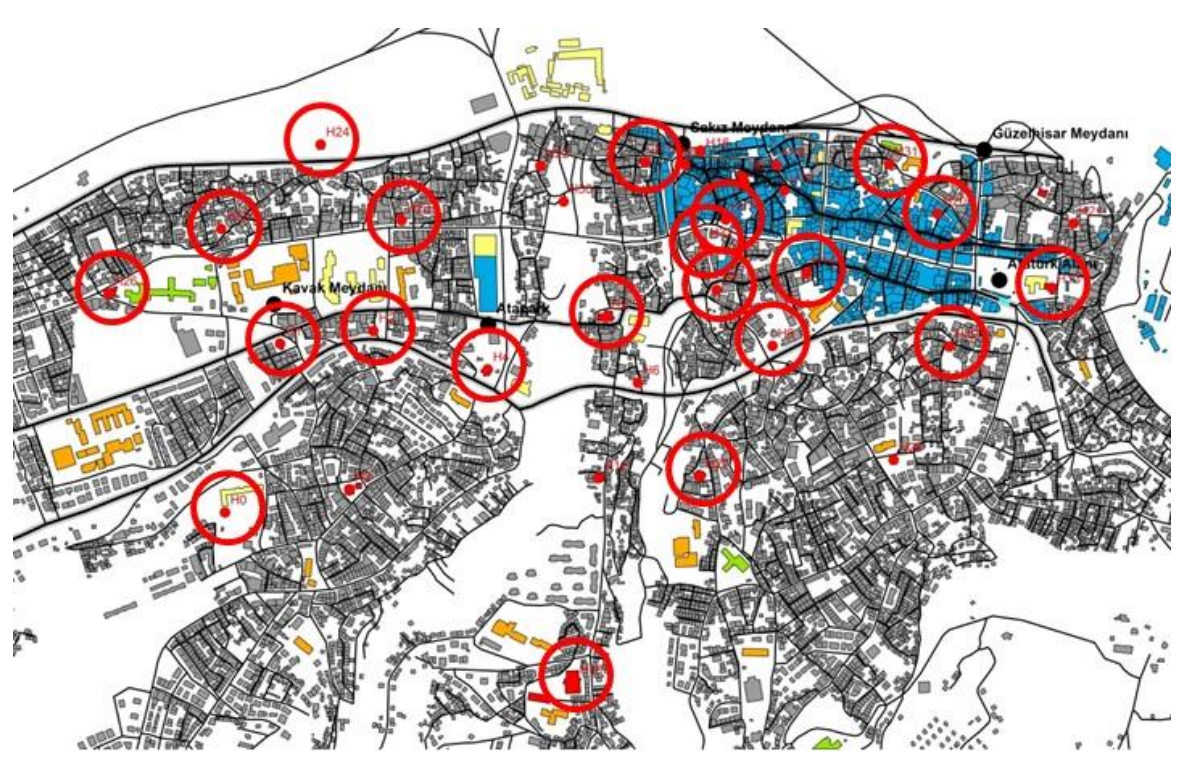

Şekil 13. Yakın çevre işlev analizi.

\section{Tartışma ve Sonuç}

Dini yapılar kentle kurduğu güçlü fiziksel ve işlevsel ilişkilerin sonucunda bir taraftan kentin kolay kavranmasını, kullanıcıların kentte kolaylıkla yol ve yön bulunmasını desteklerken diğer taraftan kent kimliğinin oluşmasında da 
etkili olurlar. Bu ilişki Lynch'in imaj öğelerinden özellikle işaret öğeleri ile ilişkili tartışıldığında aşağıdaki sonuçlara varılmıştır;

- Dini yapılar öncelikli olarak ihtiyaç durumuna ve ulaşılabilirliğe göre yapılırken bazı dini yapıların özellikle yaptıranın ve yaptırılanın gücünü simgeleyecek şekilde kentin önemli noktalarında inşa edildiği görülmüştür. Bu yapılar genellikle kent strüktürü içinde kentin simgesi haline gelmekte ve kentin birer işaret öğesi olmaktadırlar.

- Dini yapılar kubbeli, minareli çan kuleli sembolleri ile kent dokusunda ve/veya siluetinde farklılığıyla öne çıarken boyutsal özellikleri sonucu çevrelerine egemen olmaktadır. Ayrıca dini yapılar avlulu yapıları, odakla buluşması, vadi ve ya geniş avlulu diğer yapılara yakın olması gibi gerek biçimlenmesi gerekse konumlanması açısından çevresinde oluşan boşluk etkisiyle daha güçlü ve etkili algılanması sonucu işaret öğesi olma potansiyelleri yüksek olmaktadır.

- Dini yapıların kent siluetinde farklı, tek ve/veya egemen olmaları sonucu işaret öğesi olma potansiyelleri yüksek olurken, bu yapıların yoğun, yüksek ve çarpık yapılaşma içinde olması işaret öğesi olma potansiyellerini azaltmaktadır.

- Dini yapılar kentsel doku içerisinde kamusal mekânlar olarak önemli alandır. Ayrıca yapıların kent odaklarında yer alması bu mekânların kentin simgeleri olarak önemini ve kullanıcıdaki yerini güçlendirmekte işaret öğesi olma potansiyellerini arttırmaktadır.

- Kentin yoğun olarak kullanılan alanlarında, yollarında ve/veya odaklarında yer alan dini yapıların işaret öğesi olma potansiyelleri yüksek olmaktadir.

- Tarihi dini yapılar geçmişten günümüze zamandaki süreklilikleri yani kalıcı olmaları sonucu işaret öğesi olma potansiyelleri yüksek olmaktadır.

- Erişim mesafesi ve hizmet alanı içerisinde tek olan, yoğun kullanılan ve ya farklı işlevleri bir arada sunan yerlere yakın olan dini yapıların işaret öğesi olma potansiyelleri yüksek olmaktadır.

- Trabzon kent merkezinde yer alan dini yapıların, işaret öğesi olma durumu bu yapıların mevcut durumuna göre fiziksel ve işlevsel açıdan değerlendirildiğinde aşağıdaki sonuçlara varılmıştır;

- Fiziksel ilişki açısından Hamza Paşa Camii (H1), Gülbahar Hatun Camii (H4), Orta Hisar Büyük Fatih Camii (H5), Çarşı Camii (H8) ve İskender Paşa Camii (H13) kent odaklarıyla ve kentin önemli yollarıyla ilişkili kalıcı yapılardır. Ayrıca Gülbahar Hatun Camii (H4), Orta Hisar Büyük Fatih Camii (H5), ve Çarşı Camii (H8) çevrelerine egemen yapılardır. Hamza Paşa Camii 
(H1), Gülbahar Hatun Camii (H4), Orta Hisar Büyük Fatih Camii (H5), ve İskender Paşa Camii (H13) ise boşluktan yaklaşılması sonucu güçlü perspektifler oluşturması nedeniyle öne çıkan yapılardır.

- İşlevsel ilişki açısından değerlendirildiğinde Askeri Camii (H0), Gülbahar Hatun Camii (H4), Hızır Bey Camii (H23), Yalı Camii (H25) ve Yeni Cuma Camii (H27) öne çıkan dini yapılardır. Askeri Camii (H0), Hızır Bey Camii (H23), ve Yalı Camii (H25) erişim mesafesi içinde tek olmaları, Gülbahar Hatun Camii (H4), Hızır Bey Camii (H23), Yalı Camii (H25) ve Yeni Cuma Camii (H27), hizmet alanı içinde tek olmaları, Gülbahar Hatun Camii (H4), Hızır Bey Camii (H23), Yalı Camii (H25) ve Yeni Cuma Camii (H27) çevrelerinde işlev çeşitliliğinin fazla olması ve yoğun kullanılan işlevlerin olması Askeri Camii (H0) ise çevrelerinde yoğun kullanılan işlevlerin olması nedeniyle öne çıkan yapılardır.

- Sonuç olarak Trabzon kent merkezinde yer alan biçimsel, işlevsel, anlamsal ve/veya simgesel açıdan işaret öğesi niteliği taşıyan 33 dini yapıdan sadece 6 tanesi fiziksel ve işlevsel açıdan işaret öğesi olma potansiyelli taşımaktadır. Bunlar Hamza Paşa Camii (H1), Gülbahar Hatun Camii (H4), Ortahisar Büyük Fatih Camii (H5), İskender Paşa Camii (H13), Hızırbey Camii (H23) ve Yalı Camii (H25)'dir. Öne çıkan bu dini yapılar o işaret öğesi olma potansiyeli yüksek yapılar olarak kent kimliğinde etkili yapılardır (Şekil 14). 

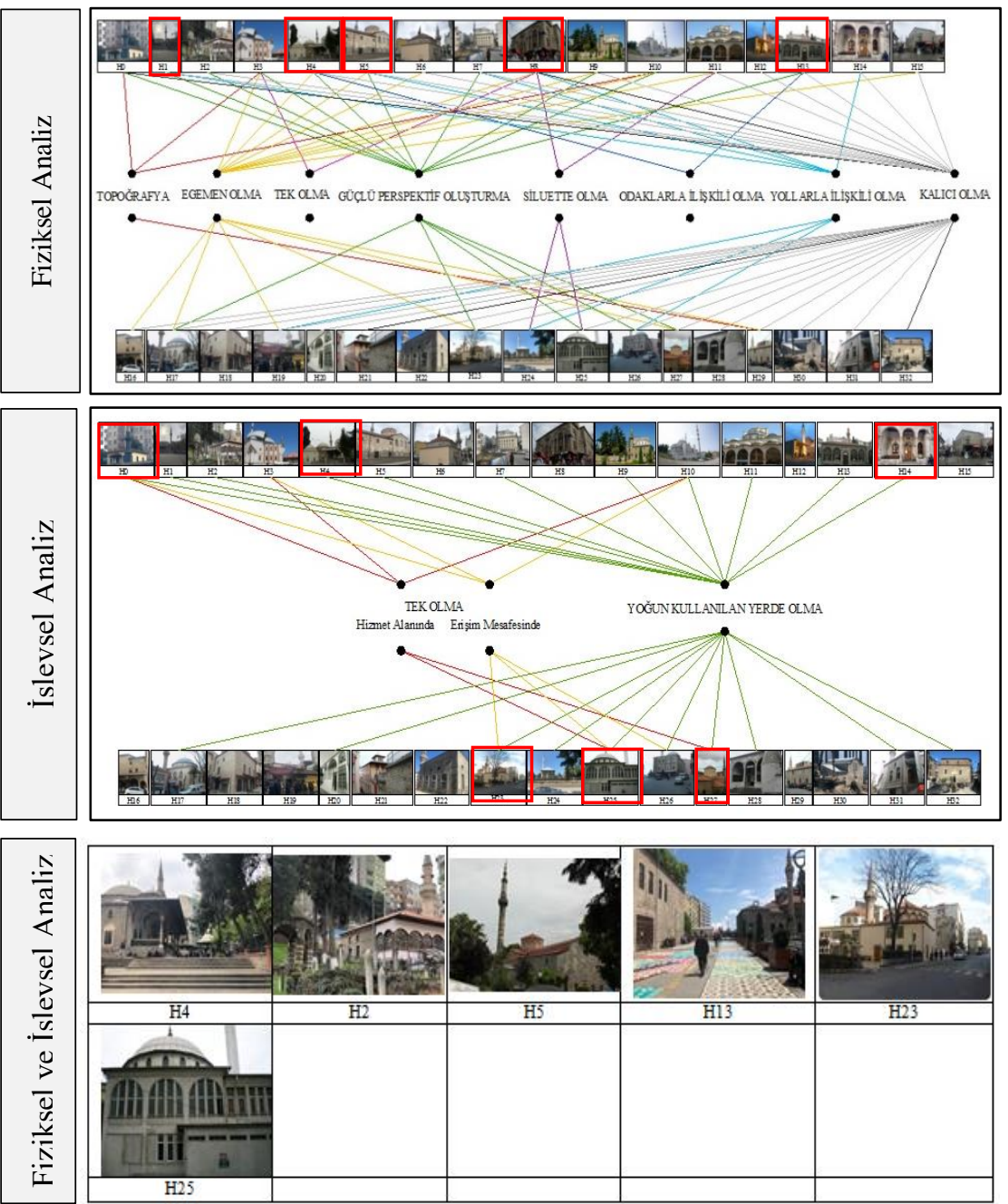

Şekil 14. Fiziksel ve/veya işlevsel analizlerde öne çıkan dini yapılar.

Özetle işaret öğesi olma direk hedefi olabilen kent imajında dolayısıyla kent kimliğinde etkili dini yapıların tasarımında yapının biçimlenmesi kadar kentle kurduğu ilişki de dikkate alınmalıdır. Yapının kentle kurduğu ilişki tek başına tasarımın güçlü yönünü oluşturabilmektedir. Dolayısıyla, kent kimliği üzerinde etkili olan dini yapıların çevrelerinde yapılacak düzenlemelerde ve ya yeni yapılacak dini yapıların yer seçiminde, dini yapıların işaret öğesi olma potansiyellerinin yüksek olmasını sağlayan fiziksel, işlevsel, simgesel ve anlamsal açıdan güçlü yönlerin desteklenmesi ve sürekliliğinin sağlanması, kent kimliğinin korunması için bir gereklilik olmaktadır. 


\section{Extended Abstract}

\section{An Evaluation on the Relationship Between Religious Buildings and Urban Identity: The Case of Trabzon}

\author{
Demet Yilmaz Yildirim \\ ORCID: 0000-0001-8894-3385
}

\author{
Şeyma Yetim \\ ORCID: 0000-0001-9741-9761
}

Religious buildings stand out differentiating from other buildings in the urban structure with their location and forms. These buildings, which are formed in different ways such as domes, minarets, towers and courtyards, dominate the urban structure and constitute strong perspectives. They can be seen in the most effective position of city topography, sometimes in nodes of cities. Even in some cities, especially the religious buildings are the most effective buildings in the city silhouette. In addition to these physical features, religious buildings can be functionally unique in the service area and accessibility, and can be placed in intensively used or multifunctional environments. All of them increases the potential of religious buildings to be landmark of the city. Therefore, religious buildings are effective in the image of the city and therefore in the identity of the city.

In this study, the place of religious buildings in the whole city is discussed physically and functionally. In this respect, it is aimed to reveal the relationship between religious buildings and the city in Trabzon through their potential as a landmark.

The assumptions of the study in terms of physically;

- Religious buildings come to the fore in the urban fabric and / or city silhouette, as a result of their unique forms, dimensional differences, dominating their surroundings and being unique in their surroundings. Therefore, the perceptibility of these buildings is strong and their potential to be landmarks is high.

- The religious buildings located at the high points of the city, which is topographically mountainous, are highly visible. This situation, on the one hand, increases the potential of the religious buildings to be striking with its strong 
context, and on the other hand, to be a landmark by making it stand out both in the city and in the city skyline.

- Religious buildings that are located in or perceived from these roads in the city centers where social life flows and which are used extensively and / or on the roads that form the important arteries of the city have a high potential to be a landmarks.

- Religious buildings generally consist of closed, open and semi-open spaces. This spatial hierarchy and focus, being in or near wide spaces such as valleys, enhances the perception of the religious building and increases its potential as a landmark.

- Persistence is an important feature of a building to be a landmark. Religious buildings are buildings with high semantic, symbolic and permanence values. The continuity of these structures in time increases their potential to be landmarks.

In terms of functionality;

- The fact that the religious building is the only religious building in the settlement area where it is located and serves a wide area increases the potential of being a landmark of the religious building.

- Having more than one religious building within reach causes distraction of the user. Therefore, religious buildings, which are the only ones within reach, have a high potential to be landmarks. It was created in the form.

In this study, physical and functional analyzes are carried out in order to reveal the relationship between religious buildings and the city in Trabzon with the potential of being a landmark. In this analysis, ArcMap 10.3 and ArcScene 10.3 are used over GIS (Geographic Information System).

In this study these results are obtained that are the relationship between the religious buildings and the city is examined through the "landmark" which is one of the elements of identity identified by Lynch. Firstly, in order to reveal the place of the religious buildings in Trabzon in the whole city, in terms of physical analysis, topography, the relationship with paths and nodes, occupancy, closeness, distance to nodes, effect silhouette on the imaginability and permanence analysis are made. Secondly, in order to reveal the functional relationship between religious buildings and the city, service area, accessibility and close environment function analysis are also made. In each analysis, prominent religious buildings are identified.

In conclusion, religious buildings, which can be a direct target of being a landmark or are one of the buildings have high potential about being landmark, should be taken into consideration in analyzing the relationship between 
the religious buildings and the city as well as design of them. The originality of this relationship formed the strong aspect of the design. Therefore, the historical value, forms, positions and effects of the religious buildings affect the city identity. When these headings are considered in Trabzon city center, Hamza Paşa Mosque, Gülbahar Hatun Mosque, Büyük Fatih Mosque, İskender Paşa Mosque, Hizırbey Mosque and Yalı Mosque come to front. All these data should be taken into account in the design of buildings environments.

Within the scope of the study are aimed to create data in the arrangements to be made in the existing religious building environments or in the selection of the place of the new religious building. The study is unique in terms of the area under consideration and the technique used.

\section{Kaynakça/References}

Selimiye Camii yapıya zarar veren çimentodan temizlenecek. (2018a). Anadolu Ajansı. https://www.yeniakit.com.tr/haber/selimiye-camii-yapiya-zarar-veren-cimentodan-temizlenecek-463243 adresinden erişilmiştir.

Köln Katedralinin örtüleri kayboldu. (2018b). Anadolu Ajansı. https://www.hurriyet.com.tr/avrupa/koln-katedralinin-ortuleri-kayboldu-40913588 adresinden erişilmiştir.

Çamlıca Camii vs Sultanahmet Camii. (2020). Uludağ Sözlük. https://galeri.uludagsozluk.com/r/\%C3\%A7aml\%C4\%B1ca-cami-vs-sultanahmet-cami-639911

Çevre ve Şehircilik Bakanlığı. (2019). Mekansal planlar yapım yönetmeliği. https://webdosya.csb.gov.tr/db/e-plan/webmenu/webmenu13088.pdf adresinden erişilmiştir.

Appleyard, D. (1969). Why buildings are known. Environment and Behavior,1, 131-156.

Appleyard, D., Lynch, K. ve Myer, J.R. (1964). The view of the road. Cambridge: Cambridge Massachusetts Institute of Technology.

Atıc, E. (2018). Türkiye'deki kilise ve külliye yapılarmnn okunması. Yüksek Lisans Tezi. Anadolu Üniversitesi, Eskişehir.

Bhatta, B. (2009). Analysis of urban growth pattern using remote sensing abd GIS: A case study of Kalkata, India. International Journal of Remote Sensing, 30 (18), 4733-4746.

Bülü̧̈, E. (2017). Infill uygulamalarla yer ve mekan kimliğinin değişimi. Yayımlanmamış Yüksek Lisans Tezi. Necmettin Erbakan Üniversitesi, Konya.

Cullen, G. (1961). Townscape. London: Architectural Press.

Çetin, M. (2015). Using GIS analysis to assess urban green space in terms of accesibility: case study in Kütahya. International Journal of Sustaninable Development and World Ecology, 22 (5), 420-424.

Çöl, Ş. (1998). Kent kimliğini oluşturan faktörler ve günümüz kentlerini kimlikli klmak için bir sistem önerisi. Yayınlanmamış Doktora Tezi. Mimar Sinan Üniversitesi, İstanbul.

Diker, M. (2014). Kent kimliğinin oluşmasında ibadet yapılarmnn yeri ve önemi: Antakya örneği Yüksek Lisans Tezi Yıldız Teknik Üniversitesi, İstanbul. 
Doğan, F. (2016). Tarihsel süreç içerisinde kültürel değişimin fiziksel ve algısal değişim bağlamında irdelenmesi: Trabzon kent meydanları Örneği. Doktora Tezi. Karadeniz Teknik Üniversitesi, Trabzon.

Eczacıbaşı Sanat Ansiklopedisi 1997. (1997). İstanbul: Yapı Endüstri Merkezi Yayınları.

Emlak Haber Ajansı (2020). Körfez ülkelerinin yeni gözdesi: Trabzon. https://www.emlakhaberajansi.com/korfez-ulkelerinin-yeni-gozdesi-trabzon.html adresinden erişilmiştir.

Erbilgin, S. H. (2017). Erken dönem kilise mimarisi ve dinsel dramın ilk örneklerinde mekan. Sahne ve Müzik Eğitim-Araştırma Dergisi, 5, 156-171.

Erdem, N., İnce, H. (2016). Tarihi kilise ve havralarda kıble yönünün GNSS ölçmeleri ile araştırılması. 8. Ulusal Mühendislik Ölçmeleri Sempozyumu, Yıldız Teknik Üniversitesi, İstanbul.

HD Wallpaper: italy,rome,vatican, saint pierre, cathedral, dome, tiber. (2019). https://www.wallpaperflare.com/italy-rome-vatican-saint-pierre-cathedral-dometiber-wallpaper-zsykx adresinden erişilmiştir.

TDV . (2012). İslam Ansiklopedisi 2012. İstanbul: Türk Diyanet Vakfı İslam Araştırmaları Merkezi Yayınları.

Kalın, A. (2004). Çevre tercih ve değerlendirmesinde görsel kalitenin belirlenmesi ve geliştirilmesi: Trabzon sahil bandı örneği. Doktora Tezi. Karadeniz Teknik Üniversitesi, Trabzon.

Kostof, S. (1993). The city shaped: urban patterns and meanings, Through History, New York: Thames\&Hudson.

Kuban, D. (2010). Mimarlık kavramları, İstanbul: Yem Yayınları.

Levi, D. ve Kocher, S. (2012). Perception of sacredness at heritage religious sites. Environment and Behavior, 45 (7), 912-930.

Lynch, K. (1960). Kent imgesi, İstanbul: Türkiye İş Bankası Kültür Yayınları.

Milne, J. A. ve Sear D. A. (1997). Modelling river channel topography using GIS. International Journal Geographical Information Science, 11 (5), 499-519.

Mango, C. (2006). Bizans mimarisi, Ankara: Rekmay Ltd. Şti.

Marchesano, P. R. (2007). Brief history of the organsof the cathedral basilica of SS. Peter and Paul. The Tracker, 51 (3). 20-30.

Nuroğlu, C. (2014). Kilisenin düzeni, İstanbul: Hristiyan Kitaplar Yayınları.

Öz, Ş. (2013). Mescid/cami İslam kuruluş tarihi. Ankara: Grafiker Yayınları.

Özen, H., Tuluk, Ö. İ., Engin, H. E., Düzenli, H. İ., Sümerkan, M. R., Tutkun, M., Üstün Demirkaya, F., ve Keleş, S. (2010). Trabzon kent içi kültür varlıkları envanteri, Trabzon: T:C: Trabzon Valiliği İl Kültür ve Turizm Müdürlüğü Yayınları.

Park, S. J. (2012). Measuring public library accessibility: a case study using GIS. Library and Information Science Research, 34 (1), 13-21.

Peker, A. U. (2006). Hunad külliyesi. Tasarmm Merkezi Dergisi, 1, 22-29.

Ramazanoğlu, G. (2008). 16. yüzyılda Osmanlı külliyeleri. Ç.Ü. Sosyal Bilimler Enstitüsü Dergisi, 17 (3), 333-344.

Rossi, A. (2006). Şehrin mimarisi. İstanbul: Kanat Yayınları. 
Sargin, H. (2012) Havra, kilise ve cami iç mekanlarına ibadethane kimliği kazandıran mekansal imge ve sembollerine ilişkin ortak kavramlar. Eskişehir: Anadolu Üniversitesi Yayınları.

Sarıhan, F. Z. (2015). Türk mimarisinde cami imajı algısı (biçim-form üzerinden bir yaklaşım) Yüksek Lisans Tezi. Fatih Sultan Mehmet Vakıf Üniversitesi, İstanbul.

Onebilgi. (2020). Sultan Ahmet Camii http://www.onebilgi.com/sultan-ahmet-camii.html adresinden erişilmiştir.

Sultan Ahmet Camiinin bilinmeyenleri. (2020). Yeni Akit. https://www.yeniakit.com.tr/foto-galeri/sultanahmet-camiinin-bilinmeyenleri-2744/1 adresinden erişilmiştir.

Kuşbakışı Trabzon bir başka güzel (2016). Trabzon Haberleri. https://www.mynet.com/kusbakisi-trabzon-bir-baska-guzel-180103282434\#12453819 adresinden erişilmiştir.

Wescott, A. (2018). Old St. Peter's Basilica. https://www.youtube.com/watch?v=ej4OvYFnyTQ adresinden erişilmiştir.

Yetim, Ş. (2019). Dini yapılarnn işaret öğesi olma potansiyeli: Trabzon örneği. Yüksek Lisans Tezi. Karadeniz Teknik Üniversitesi, Trabzon. 